HJIMB Vol 1, No. 2 2019, pp: 24-33

https://doi.org/10.30606/hjimb

\title{
HIRARKI
}

Jurnal Ilmiah Manajemen dan Bisnis

http://iournal.upp.ac.id/index.php/Hirarki

\section{ANALISA TOTAL SERVICE QUALITY MANAGEMENT TERHADAP KEPUASAN PELANGGAN GO-JEK}

\author{
Astri Ayu Purwati, Hanif \\ Program Studi Manajemen, Sekolah Tinggi Ilmu Ekonomi Pelita Indonesia, \\ Pekanbaru, Indonesia
}

\begin{tabular}{l} 
Info Artikel \\
\hline Sejarah Artikel: \\
Diterima 08 Agustus \\
2019 \\
Disetujui 15 Oktober \\
2019 \\
Dipublikasikan 30 \\
Oktober 2019 \\
\hline Keywords: \\
Go-jek, TSQM, Service \\
quality
\end{tabular}

\begin{tabular}{l} 
Abstrak \\
\hline Penelitian ini dilakukan untuk menganalisis pengaruh Total Service \\
QualityManagement terhadap kepuasan pelanggan Go-Jek, Pada mahasiswa \\
pengguna Go-Jek di perguruan tinggi Pelita Indonesia Pekanbaru. dengan \\
menggunakan 5 dimensi TSQM. Teknik yang digunakan untuk mengambil sampel \\
penelitian adalah purposive sampling. Dari 100 sampel yang dikumpulkan. Dalam \\
penelitian ini uji validitas dan reliabilitas dilakukan untuk memastikan validitas dan \\
reliabilitas instrumen penelitian. Data yang dianalisis yang digunakan dalam \\
penelitian ini adalah regresi linier berganda, uji t dan uji F. Hasil penelitian \\
menunjukkan bahwa terdapat pengaruh Pengaruh Total Service Quality management \\
terhadap kepuasan pelanggan pada dimensi mutu fisik, pendukung mutu fisik, mutu \\
perusahaan, mutu teknikal dan mutu interaktif terhadap kepuasan pelanggan Go-Jek, \\
baiksebagian maupun simultan dari semua dimensi. \\
OTAL QUALITY MANAGEMENT SERVICE TO CUSTOMER \\
$\boldsymbol{O}$-JEK
\end{tabular}

\section{Abstract}

This study was conducted to analyze the effect of Total Service QualityManagement to customer satisfaction Go-Jek, On the Go-Jek student in college Pelita Indonesia Pekanbaru. using 5 dimensions TSQM. The technique used to take samples of the research is purposive sampling. Of the 100 samples collected. In this study the validity and reliability tests conducted to ascertain the validity and reliability of research instrument. The data analyzed were used in this research is multiple linear regression, $t$ test and F test results showed that there are significant Effect of Total Service Quality management to customer satisfaction on the dimensions of the physical quality, physical quality support, the company's quality, technical quality and interactive quality to customer satisfaction Go-Jek, either partially or simultaneously from all dimensions.

$\begin{array}{lr}{ }^{凶} \text { Alamat korespondensi : } & \text { ISSN } \\ \text { Jln. Jend. A. Yani no 78-88 Pekanbaru, Riau } & 2684-9666 \text { (cetak) } \\ \text { astri.ayu@lecturer.pelitaindonesia.ac.id } & 2684-8503 \text { (online) }\end{array}$




\section{PENDAHULUAN}

Pada zaman sekarang perkembangan teknologi informasi sangatlah cepat. Seiring dengan berjalannya waktu perkembangan teknologi menjadi penting karena mempermudah manusia dalam melakukan berbagai kegiatan. Salah satu teknologi yang sudah menjadi megatrend adalah penggunaan internet.

Internet di Indonesia yang selalu meningkat tiap tahunnya dapat dijadikan sebagai peluang usaha bagi industri-industri inovatif yang berbasiskan internet. Dengan melihat peluang bisnis berbasis internet yang sangat menjanjikan membuat pelaku bisnis menggabungkan internet dan transportasi, seperti ojek online dan juga taksi online. Salah satu perusahaan pencetus layanan transportasi berbasis aplikasi online adalah Go-jek yang menyediakan layanan ojek online.

Tabel 1. Pangsa pasar Go-Jek, Grab dan Uber

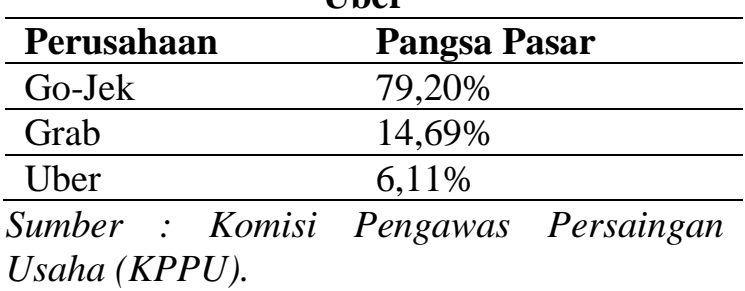

Berdasarkan tabel 1 diatas dimana KPPU melakukan perbandingan antara Perusahaan Transportasi Online Go-Jek, Grab dan Uber dimana hasil perbandingan tersebut menunjukkan bahwa Go-Jek memiliki pangsa pasar yang paling tinggi dari pada Grab dan Uber, sebesar $72,20 \%$ diikuti pangsa pasar berikutnya yaitu Grab sebesar 14,69\% dan Uber paling rendah sebesar $6,11 \%$ pangsa pasar. Hal ini menunjukkan bahwa Go-Jek dengan pangsa pasar lebih dari 50\% merupakan market leader dalam Perusahaan transportasi online.

Banyak faktor yang dapat mempengaruhi tingkat kepuasan mahasiswa pengguna gojek salah satunya adalah penerapan Total Quality Management TQM. yang diterapkan pada sektor layanan jasa bisa disebut dengan Total Quality Service (TQS) atau lebih dikenal Total Service Quality Management (TSQM).

Manajemen operasional yang baik didukung skill dan semangat kerja karyawan yang tinggi merupakan hal yang penting dalam pencapaian keberhasilan perusahaan transportasi. Total Service Quality Management (TSQM) adalah komitmen yang tepat untuk mengoprasionalisasi konsep yang berfokus pada pelanggan, menetapkan standar kinerja jasa dan memelihara antusiasme pelanggan pada segala waktu dan pangsa pasar (Stamatis dalam Munjiati Munawaroh, 2015).

Penelitian yang melakukan studi analisis TSQM terhadap kepuasan pelanggan (Ika \& Pungki 2011, Prastowo 2010, Aprinawati, 2011, Darmansyah, 2012, Anang, 2016). Penelitian ini menemukan bahwa Total Service Quality Management berpengaruh terhadap kepuasan palanggan.

$$
\text { Manajemen adalah bagaimana }
$$

manager dapat mengenali peran dan pentingnya para pihak yanng akan menunjang pencapaian tujuan perusahaan (Ismail Solihin, 2010). Meurut daft dan Marcis (2007) dalam Ismail solihin (2010) management adalah " the art of getting things done through people " ( seni menyelesaikan suatu pekerjaan melalui orang lain ). Ismail solihin (2010) menambahkan bahwa tugas penting manajer adalah menetapkan arah tujuan perusahaan, memberikan kepemimpinan untuk mencapai tujuan tersebut serta membuat keputusan mengenai bagaimana menggunakan sumber daya organisasi untuk mencapai tujuan tujuan yang telah diciptakan.

Pemasaran merupakan salah satu kegiatan-kegiatan pokok yang dilakukan oleh perusahaan untuk mempertahankan kelangsungan hidupnya, untuk berkembang dan untuk mendapatkan laba. Assauri (2010:5) mendifinisikan pemasaran sebagai usaha untuk menyediakan dan menyampaikan barang dan jasa yang tepat kepada orangorang yang tepat pada tempat dan waktu serta harga yang tepat dengan promosi dan komunikasi yang tepat.

Secara lebih formal, menurut Abdullah \& Tantri (2012:2) adalah suatu sistem total dari kegiatan bisnis yang di rancang untuk merencanakan, menentukan harga, mempromosikan dan mendistribusikan barang-barang yang dapat memuaskan keinginan dan jasa baik kepada para konsumen saat ini maupun konsumen potensial.

Pemasaran sebagai rangkaian kegiatan juga dinyatakan oleh Willian J. Satanton dalam 
Dharmmesta \& Handoko (2008:3-4) yang mendifinisikan pemasaran sebagai suatu sistem keseluruhan dari kegiatan-kegiatan usaha yang ditunjukan untuk merencanakan, menentukan harga, mempromosikan dan mendistribusikan barang dan jasa yang dapat memuaskan kebutuhan baik kepada pembeli yang ada maupun pembeli potensial.

Dengan demikian maka arti pemasaran jauh lebih luas daripada sekedar penjualan. Pemasaran mencakup usaha mengidentifikasi kebutuhan konsumen yang perlu dipuaskan, menentukan produk yang hendak diproduksi, menentukan harga produk yang sesuai, menentukan cara-cara promosi dan penyaluran/penjualan produk tersebut. Jadi kegiatan pemasaran adalah kegiatankegiatan yang saling berhubungan sebagai suatu sistem.

Jasa merupakan semua aktivitas ekonomi yang hasilnya bukan berbentuk produk fisik dan berbentuk atau konstruksi, yang umumnya yang dihasilkan dan dikonsumsi secara bersama serta memberikan nilai tambah misalnya kenyamanan, hiburan, kenangan,atau kesehatan bagi konsumen Lupiyoadi dan (Hamdani,2006).

Kotler (2008:111) mendifinisikan jasa sebagai setiap tindakan atau kegiatan yang dapat ditawarkan oleh suatu pihak lain, pada dasarnya bersifat intangible (tidak berwujud fisik) dan tidak menghasilkan kepemilikan sesuatu. Produksi jasa bisa berhubungan dengan produk fisik atau sebaliknya. Tjiptono (2005:3) mendifinisikan jasa sebagai tindakan atau perbuatan yang dapat ditawarkan oleh suatu pihak lain, yang pada dasarnya bersifat tidak berwujud fisik dan tidak menghasilkan kepemilikan sesuatu.

Berdasarkam beberapa definisi diatas dapat disimpulkan bahwa jasa merupakan sebuah tindakan atau perbuatan yang bersifat intingible atau tidak berwujud yang ditawarkan untuk dijual kepada pihak lain yaitu pengguna jasa.

Jasa memiliki beberapa karakteristik utama yang membedakannya dengan barang. Karakteristik jasa tersebut adalah (Tjiptono,2005): (1) Bukti langsung (tangibility) Jasa merupakan sesuatu yang tidak berwujud, artinya tidak dapat dilihat,diraba, dicium atau didengar sebelum dibeli. (2) Tidak dapat dipisahkan
(Inseparability) Berbeda halnya dengan barang-barang fisik yang di produksi, disimpan dalam persediaan, didistribusi, melalui berbagai macam penjual dan pada saat jasa diproduksi dan langsung mengkonsumsi jasa tersebut. (3) Bervariasi (Variability) Jasa sangat bervariasi karena sangat tergantung pada siapa yang menghasilkan. (4) Tidak tahan lama (Perishability) Jasa merupakan komuditas tidak tahan lama dan tidak dapat disimpan. Dengan demikian, bila suatu jasa tersebut akan berlalu begitu saja. Hal ini mengakibatkan kapasitas produksi menjadi faktor yang kritikal.

Total Quality Management mengacu pada penekanan kualitas yang meliputi organisasi secara keseluruhan mulai dari pemasok sampai ke pelanggan. TQM menekankan pada komitmen oleh manajemen untuk memiliki terus menerus menuju keunggulan dalam segala aspek barang dan jasa yang penting bagi pelanggan. Heizer J \& Render B (2015).

Total Service Quality Management (TSQM) atau bisa disebut juga Total Quality Service adalah komitmen yang tepat untuk mengoperasionalisasi konsep yang berfokus kepada pelanggan, menetapkan standar kinerja jasa dan memelihara antusiasme pelanggan pada segala waktu dan pangsa pasar. Stamatis dalam Ika N Q \& Pungki A R (2011). Total Service Quality Management (TSQM) merupakan konsep strategik dengan melibatkan manajer dan pekerja dengan menggunakan metode kualitatif maupun kuantitatif untuk terus menerus memperbaiki proses organisasi untuk memenuhi dan melampaui kebutuhan pelanggan (Hedriana dalam Munjiati Munawaroh, 2015).

Lima dimensi TSQM menurut Said dalam Ika \& Pungki (2011) yang dianggap dapat mengukur kualitas perusahaan jasa pelayanan alat transportasi diantaranya ialah:

Mutu fisik, adalah mutu/kualitas dari segi fisik (Kenderaan) yang mampu mempengaruhi kepuasan pelanggan. Mutu fisik dari obyek penelitian yang dilakukan said dalam Ika \& Pungki (2011) yaitu; kondisi fisik ruang parkir, kondisi fisik ruang tunggu, kondisi tata ruang, kenyamanan dan kebersihan, serta mutu tempat duduk penumpang. 
Pendukung mutu fisik, adalah mutu/kualitas yang mendukung kinerja atau manfaat dari fasilitas fisik yang dapat mempengaruhi kepuasan pelanggan. Pendukungung mutu fisik dari penelitian yang dilakukan said dalam Ika \& Pungki (2011) yaitu; alat perlengkapan keselamatan, dan fasilitas tambahan lainnya.

Mutu perusahaan/lembaga, Adalah mutu/kualitas dari perusahaan atau lembaga penyedia layanan, yang dapat mempengaruhi kepuasan pelanggan dan biasanya didasarkan pada kinerja operasional perusahaan. Mutu perusahaan/lembaga pada obyek yang dilakukan said dalam Ika \& Pungki (2011) yaitu; ketepatan waktu, kemudahan, profesionalitas,dan tanggung jawab perusahaan.

Mutu teknikal, adalah mutu/kualitas dari segi teknis dalam hal pelayanan yang dapat mempengaruhi kualitas pelanggan. Mutu teknikal dari obyek penelitian yang dilakukan Said dalam Ika \& Pungki (2011) yaitu; pengetahuan petugas/pejabat dalam bidang pelayanan, pengetahuan petugas/pejabat dalam bidang pelanggan, pengetahuan petugas/pejabat dalam bidang koordinasi kerja, pengetahuan petugas/pejabat dalam bidang kerjanya, kecepatan petugas/pejabat dalam bekerja dan ketangkasan petugas/pejabat dalam bekerja.

Mutu interaktif, adalah mutu/kualitas yng dinilai dengan performa dan kualitas interaktif atau kemampuan berkomunikasi pihak perusahaan dengan pelanggan dan hal ini dapat mempengaruhi kepuasan pelanggan tersebut. Mutu interaktif dalam obyek penelitian yang dilakukan oleh Said dalam Ika \& Pungki (2011) yaitu; memberikan informasi pada pelanggan, penanganan dalam kecelakaan, kejujuran petugas/pejabat dalam bekerja, keramahan petugas/pejabat dalam bekerja, mental petugas/pejabat dalam pelayanan, memecahkan masalah dengan cepat, koordinasi kerja petugas/pejabat dalam menangani masalah memberikan perhatian kepada pelanggan dan saling pengertian atau toleransi.

Tujuan utama dari TSQM ini ialah untuk mereorientasi sistem manajemen, prilaku staf, fokus organisasi dan prosesproses pengadaan pelayanan sehingga lembaga penyedia pelayanan bisa berproduksi lebih baik, pelayanan yang lebih efektif yang memenuhi kebutuhan, keinginan dan keperluan pelanggan. Sedangkan manfaat jika perusahaan penyedia layanan jasa menerapkan TSQM diantaranya perbaikan-perbaikan kualitas pelayanan, pengurangan biaya dan kepuasan pelanggan. Perbaikan progresif dalam sistem manajemen dan kualitas pelayanan menghasilkan peningkatan kepuasan pelanggan. Manfaat lain yang bisa dilihat dari penerapan TSQM ini ialah peningkatan keahlian, semangat dan percaya diri dikalangan staf pelayanan publik,perbaikan hubungan antara penyedia layanan jasa dengan pelanggan, peningkatan akuntabilitas dan transparasi perusahaan penyedia layanan jasa, serta peningkatan produktifitas dan efesiensi pelayanan publik.

Menurut Kotler (2002) kepuasan pelanggan adalah perasaan senang atau kecewa seseorang yang muncul setelah membandingkan antara persepsi atau kesannya terhadap kinerja berada di bawah harapan, pelanggan tidak puas. Tapi, jika kinerja melebihi harapan, pelanggan amat puas dan senang.Jika kinerja yang dirasakan di bawah harapan, pelanggan tersebut akan merasa dikecewakan, jika kinerja memenuhi harapan pelanggan, pelangganakan merasa puas, sedangkan jika kinerja melebihi harapan maka pelanggan akan merasa sangat puas. Kepuasan ini tentu akan dapat dirasakan setelah pelanggan yang bersangkutan mengkonsumsi produk tersebut.

Pelanggan merasa puas bila harapannya terpenuhi atau akan sangat puas bila harapan pelanggan terlampaui. Menurut Irawan (2004 : 37), ada lima dimensi utama kepuasan pelanggan, yaitu : (1) Price (Harga) Untuk pelanggan yang sensitif, biasanya harga murah adalah sumber kepuasan yang penting karena mereka akan mendapatkan value for money yang tinggi. Komponen harga ini relatif tidak penting bagi mereka yang tidak sensitif tehadap harga. (2) Service Quality (Kualitas Layanan) Service quality sangat tergantung dari tiga hal yaitu sistem, teknologi dan manusia. (3) Product Quality ( Kualitas Produk) Pelanggan merasa puas setelah membeli dan menggunakan produk tersebut apabila kualitas produk yang baik. (3) Emotional Factor ditunjukkan oleh konsumen atas kepuasan yang diperoleh mereka dalam 
menggunakan suatu produk/jasa yang menimbulkan rasa bangga dan rasa percaya diri. (4) Efficiency (Kemudahan) Kemudahan dalam meperoleh produk atau jasa tersebut dan kemudahan dalam pembayaran dapat membuat pelanggan akan semakin puas bila relatif mudah, nyaman dan efisien dalam mendapatkan suatu produk atau pelayanan.

Menurut Tjiptono (2005: 140) ada beberapa manfaat jika perusahaan dapat memaksimalkan tingkat kepuasan pelanggannya, antara lain adalah: (1) Terjalin relasi hubungan jangka panjang antara perusahaan dan parapelanggannya. Terbentuknya peluang pertumbuhan bisnis melalui pembelian ulang, cross-selling dan upselling. (3) Terciptanya loyalitas pelanggan. (4)Terjadinya rekomendasi dari mulut ke mulut yang positif, berpoten simenarik pelanggan baru dan menguntungkan bagi perusahaan. (5)Reputasi perusahaan dan persepsi pelanggan semakin positif di mata pelanggan. (6) Laba yang diproleh perusahaan dapat meningkat.

Berdasarkan latar belakang permasalahan, landasan teori, dan kerangka pemikiran yang diuraikan, maka hipotesis yang ada antara lain: (1) (Mutu fisik berpengaruh signifikan terhadap mahasiswa pengguna Go-Jek di Perguruan tinggi Pelita Indonesia Pekanbaru. (2) Pendukung mutu fisik berpengaruh signifikan terhadap mahasiswa pengguna Go-Jek di Perguruan tinggi Pelita Indonesia Pekanbaru. (3) Mutu Perusahaan berpengaruh signifikan terhadap mahasiswa pengguna Go-Jek di Perguruan tinggi Pelita Indonesia Pekanbaru. (4) Mutu teknikal berpengaruh signifikan terhadap mahasiswa pengguna Go-Jek di Perguruan tinggi Pelita Indonesia Pekanbaru. (5) Mutu interaktif berpengaruh signifikan terhadap mahasiswa pengguna Go-Jek di Perguruan tinggi Pelita Indonesia Pekanbaru.

Berdasarkan teori pendukung yang dikemukakan, kualitas pelayanan akan mempengaruhi kepuasan pelanggan. Gambar 1. berikut ini merupakan suatu kerangka pemikiran yang berfungsi sebagai penuntun atau acuan yang jelas dalam penyelesaian masalah.

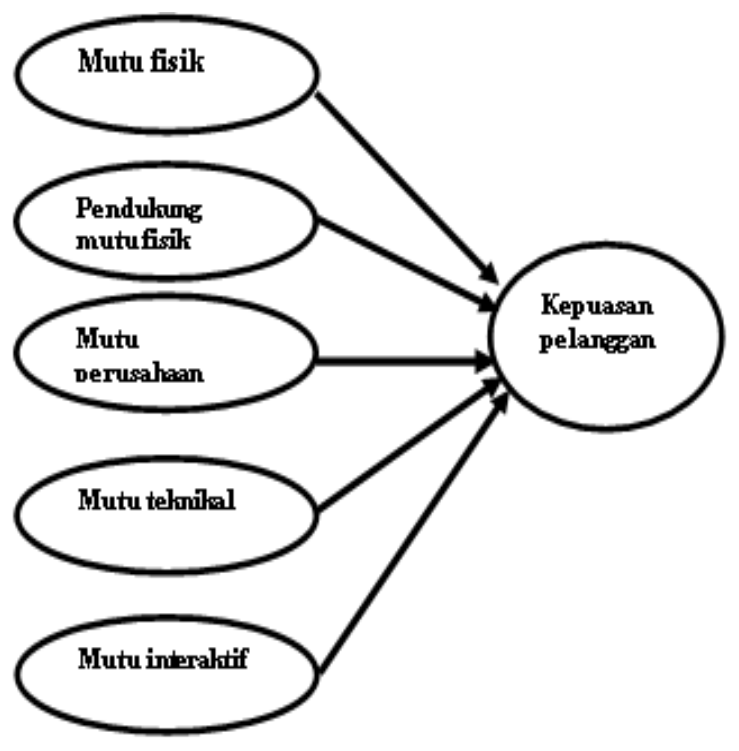

Sumber : Olahan data, 2018.

\section{Gambar 1.Kerangka Pemikiran}

\section{METODE}

\section{Tempat Dan Waktu Penelitian}

Pengumpulan data hingga pengolahan data penelitian dilakukan di Kota Pekanbaru tepatnya di Kampus Pelita Indonesia Jl. Ahmad Yani No. 78 - 88 Adapun waktu penelitian dilakukan sejak bulan Oktober 2018 sampai dengan Januari 2019.

\section{Jenis Dan Sumber Data}

Dalam penulisan ini penulis menggunakan data primer. data primer adalah data yang langsung penulis peroleh dari responden penelitian. Data-data tersebut akan dikumpulkan melalui kuesioner penelitian yang terlebih dahulu diuji validitas dan realibilitasnya.

\section{Populasi}

Populasi adalah gabungan seluruh elemen yang memiliki serangkaian karakteristik serupa yang mencakup semesta untuk kepentingan masalah riset pemasaran (Malhotra, 2015:364). Yang menjadi populasi penelitian adalah Pada mahasiswa Pelita Indonesia Pekanbaru yang pernah menggunakan Go-Jek yang jumlahnya tidak diketahui secara pasti.

\section{Sampel}


Sampel adalah bagian dari populasi yang diambil atau diidentikkan berdasarkan karakteristik dan tehnik tertentu (Malhotra, 2015:364). Penetapan jumlah sampel didasarkan kepada saran dari Roscoe (dalam Sugiyono, 2009:129) yang menyebutkan bahwa dalam penelitian menggunakan analisis multivariate seperti korelasi dan regresi berganda, maka jumlah anggota sampel minimal adalah 10 kali jumlah variabel yang akan diteliti. Penelitian ini menggunakan 5 variabel independen dan 1 variabel dependen, sehingga penetapan jumlah sampelnya. Total Sampel $=10 \times 6=60$ responden .

\section{Teknik Pengumpulan Data}

Pengumpulan data penelitian dilakukan dengan cara :

Kuesioner/angket dengan model tertutup yang berisi sejumlah daftar pernyataan yang akan ditanggapi oleh responden.

\section{Skala Pengukuran Data}

Skala pengukuran data dilakukan dengan teknik likert, yaitu skala yang dapat digunakan untuk mengukur sikap, pendapat dan persepsi seseorang tentang suatu objek atau fenomena tertentu. Skala likert memiliki dua bentuk pernyataan yaitu pernyataan positif dan negatif.

Pernyataan bersifat positif diberi skor $5,4,3,2,1$ sedangkan pernyataan bersifat negatif diberi skor 1,2,3,4,5 Siregar,(2011). Sehingga dapat disusun sebagai berikut :

$\begin{array}{ll}\text { Sangat setuju (SS) } & =5 \\ \text { Setuju (S) } & =4 \\ \text { Cukup Setuju (CS) } & =3 \\ \text { Kurang Setuju (KS) } & =2 \\ \text { Tidak Setuju (TS) } & =1 \\ \text { Uji Validitas } & \end{array}$

\section{Uji Validitas}

Uji validitas digunakan untuk mengukur sah atau tidaknya suatu kuesioner. Menurut Sugiyono (2012), untuk menguji validitas konstruk dilakukan dengan cara mengkorelasikan antara skor butir pertanyaan dengan skor totalnya. Jika nilai validitas tiap butir pernyataan lebih besar dari 0,30 atau $r \geq$ 0,30 maka butir-butir pernyataan tersebut dianggap valid.

\section{Uji Reliabilitas}

Pengujian reliabilitas dilakukan dengan cara menggunakan cronbach alpha. Jika nilai suatu variabel memiliki cronbach alpha $>0,6$ maka variabel tersebut dikatakan reliabel (Ghozali, 2013).

\section{Teknik Analisis Data}

Adapun teknik analisis data yang digunakan dalam penelitian ini adalah regresi linear berganda melalui pengujian uji $\mathrm{F}$, uji koefisien determinasi dan uji $\mathrm{T}$.

\section{HASIL DAN PEMBAHASAN}

\section{Karakteristik Responden}

Adapun deskripsi gambaran umum responden dari penelitian ini meliputi usia, jenis kelamin, pekerjaan, pendapatan, dan sampel yang digunakan sebanyak 100 responden.

Tabel 1. Karakteristik responden

\begin{tabular}{llll}
\hline $\begin{array}{l}\text { Demogra } \\
\text { fi }\end{array}$ & Kategori & $\begin{array}{l}\text { Frekuen } \\
\text { si }\end{array}$ & $\begin{array}{l}\text { Jumla } \\
\mathbf{h}\end{array}$ \\
\hline Usia & $\begin{array}{l}\text { Dibawah } \\
\text { 20 Tahun }\end{array}$ & 41 & 41 \\
& $\begin{array}{l}\text { Diatas 20 } \\
\text { Tahun }\end{array}$ & 59 & 59 \\
\hline $\begin{array}{l}\text { Jenis } \\
\text { Kelamin }\end{array}$ & Laki-Laki & 55 & 55 \\
\hline & $\begin{array}{l}\text { Perempua } \\
\text { n }\end{array}$ & 45 & 45 \\
\hline Institusi & STIE & 80 & 80 \\
\hline & STIKOM & 20 & 20 \\
\hline & Fulltime & 42 & 42 \\
\hline & Parttime & 58 & 58 \\
\hline
\end{tabular}

Sumber : data olahan (2018)

\section{Hasil Uji Validitas dan reliabilitas}

Uji validitas digunakan untuk mengukur valid tidaknya suatu koesioner. Uji coba dilakukan setelah kuesioner selesai disusun dan di uji cobakan pada sampel dari mana populasi diambil. Hasil uji validitas keseluruhan instrument penelitian menunjukkan nilai $\mathrm{R}$ hitung > $\mathrm{R}$ Tabel 0.256 yang menyatakan bahwa keseluruhan instrument penelitian dapat dinyatakan valid dan Cronbach's Alpha $>0,60$ maka dikatakan angket telah reliable.

\section{Uji F}


ANOVA $^{b}$

Tabel 6. Uji Global (Uji F)

\begin{tabular}{llll}
\hline Model & F $_{\text {hitung }}$ & $\mathbf{F}_{\text {tabel }}$ & Sig \\
\hline $\mathrm{X}_{1}, \mathrm{X}_{2}, \mathrm{X}_{3} \mathrm{X}_{4}$ & 22.731 & 3,99 & $0,000 * * *$ \\
$\mathrm{X}_{5}$ terhadap Y & & &
\end{tabular}

Sumber: Data Olahan,2018

Hasil pengujian menunjukkan bahwa

nilai sebesar Fhitung sebesar $22.731>$ Ftabel sebesar 3,09 dengan nilai signifikansi sebesar 0,000.Karena Fhitung > Ftabel, dan nilai signifikansi sebesar $0.000<\alpha$ dan bernilai signifikan pada $\alpha=0.01$ yang artinya secara bersama-sama Mutu Fisik, Pendukung Mutu Fisik, Mutu Perusahaan, Mutu Teknikal, dan Mutu Interaktif berpengaruh signifikan secara bersama-sama terhadap Kepuasan Pelanggan dan model penelitian dapat diterima.

Uji Koefisien Determinasi $\left(\mathbf{R}^{\mathbf{2}}\right)$

Uji koefisien determinasi $\left(\mathrm{R}^{2}\right)$, yaitu pengujian untuk mengetahui berapa besar kontribusi pengaruh dari variabel-variabel bebas secara serentak dalam menjelaskan variasi yang terjadi pada variabel terikat.

Tabel 7. Koefisien Determinasi $\left(\mathbf{R}^{2}\right)$ Model Summary ${ }^{b}$

\begin{tabular}{lllll}
$\begin{array}{l}\text { Mode } \\
\mathbf{l}\end{array}$ & $\mathbf{R}$ & $\begin{array}{l}\mathbf{R} \\
\text { Squar } \\
\mathbf{e}\end{array}$ & $\begin{array}{l}\text { Adjuste } \\
\mathbf{d} \quad \mathbf{R} \\
\text { Square }\end{array}$ & $\begin{array}{l}\text { Std } \\
\text { Error } \\
\text { of the } \\
\text { Estimat } \\
\text { est }\end{array}$ \\
\hline 1 & $\begin{array}{lll}.740 \\
\mathrm{a}\end{array}$ & .547 & .523 & .39846 \\
\hline
\end{tabular}

Sumber: Data Olahan, 2018

Berdasarkan pada tabel 7. diatas ini menunjukan nilai Koefisien Determinasi (Adjusted $R$ Square) sebesar 0,523. Hal ini artinya bahwa variasi Kepuasan Pelanggan dijelaskan oleh Mutu Fisik, Pendukung Mutu Fisik, Mutu Perusahaan, Mutu Teknikal, dan Mutu Interaktif sebesar $52.3 \%$, sedangkan sisanya sebesar $47.7 \%$ dipengaruhi oleh variabel lainnya yang tidak diteliti dalam model.

\section{Analisis Regresi Linier Berganda}

Untuk melihat seberapa besar mutu fisik, pendukung mutu fisik, mutu perusahaan, mutu teknikal dan mutu interaktif terhadap kepuasan pelanggan Go-Jek maka digunakan analisis regresi liner berganda.Hasil uji
Regresi Linier Berganda dapat dilihat pada tabel sebagai berikut :

\begin{tabular}{lll}
\multicolumn{2}{c}{ Tabel 8. Regresi Linier Berganda } \\
\hline Model & \multicolumn{2}{l}{$\begin{array}{l}\text { Unstandardized } \\
\text { Coeffcients }\end{array}$} \\
\cline { 2 - 3 } & B & Std.Error \\
\hline (Counstant) & 1.277 & .464 \\
\hline Mutu Fisik $\left(\mathrm{X}_{1}\right)$ & .032 & .070 \\
\hline $\begin{array}{l}\text { Pendukung } \\
\text { Fisik }\left(\mathrm{X}_{2}\right)\end{array}$ & .400 & .105 \\
\hline $\begin{array}{l}\text { Mutu Perusahaan } \\
\left(\mathrm{X}_{3}\right)\end{array}$ & .076 & .096 \\
\hline $\begin{array}{l}\text { Mutu Teknikal } \\
\left(\mathrm{X}_{4}\right)\end{array}$ & .197 & .094 \\
\hline $\begin{array}{l}\text { Mutu Interaktif } \\
\left(\mathrm{X}_{5}\right)\end{array}$ & .002 & .072 \\
\hline
\end{tabular}

Sumber: Data Olahan,2018

Berdasarkan pada tabel 8. di atas, maka persamaan regresi liniear berganda dalam penelitian ini adalah : $\mathrm{Y}=1,277+$ $0,032 X_{1}+0,400 X_{2}+0,076 X_{3}+0,197 X_{4}+$ $0,002 X_{5}+$ e Persamaan regresi linier berganda di atas dapat dijelaskan sebagai berikut : (1) Dari regresi linier berganda tersebut diperoleh nilai konstanta $(\alpha)$ sebesar 1.277 yang artinya apabila Mutu Fisik, Pendukung Mutu Fisik, Mutu Perusahaan, Mutu Teknikal, dan Mutu Interaktif nilainya adalah 0, maka Kepuasan Pelanggan nilainya adalah 1.277 satuan. (2) Nilai koefisen regresi linier berganda variabel Mutu Fisik sebesar 0,032 yang berarti jika variabel independen lainya tetap dan Mutu Fisik mengalami kenaikan 1 satuan, maka Kepuasan Pelanggan akan mengalami kenaikan sebesar 0,032 satuan. Koefisen bernilai positif artinya terjadi hubungan positif, dimana Mutu Fisik yang tinggi akan meningkatkan Kepuasan Pelanggan. (3) Nilai koefisen regresi linier berganda variabel Pendukung Mutu Fisik sebesar 0,400 yang berarti jika variabel independen lainya tetap dan Pendukung Mutu Fisik mengalami kenaikan 1 satuan, maka Kepuasan Pelanggan akan mengalami kenaikan sebesar 0,400 satuan. Koefisen bernilai positif artinya terjadi hubungan positif, dimana Pendukung Mutu Fisik yang tinggi akan meningkatkan Kepuasan Pelanggan. (4) Nilai koefisen regresi linier berganda variabel Mutu Perusahaan sebesar 0,076 yang berarti jika variabel independen 
lainya tetap dan Mutu Perusahaan mengalami kenaikan 1 satuan, maka Kepuasan Pelanggan akan mengalami kenaikan sebesar 0,076 satuan. Koefisen bernilai positif artinya terjadi hubungan positif, dimana Mutu Perusahaan yang tinggi akan meningkatkan Kepuasan Pelanggan. (5) Nilai koefisen regresi linier berganda variabel Mutu Teknikal sebesar 0,197 yang berarti jika variabel independen lainya tetap dan Mutu Teknikal mengalami kenaikan 1 satuan, maka Kepuasan Pelanggan akan mengalami kenaikan sebesar 0,197 satuan. Koefisen bernilai positifartinya terjadi hubungan positif, dimana Mutu Teknikal yang tinggi akan meningkatkan Kepuasan Pelanggan. (6) Nilai koefisen regresi linier berganda variabel Mutu Interaktif sebesar 0,002 yang berarti jika variabel independen lainya tetap dan Mutu Interaktif mengalami kenaikan 1 satuan, maka Kepuasan Pelanggan akan mengalami kenaikan sebesar 0,002 satuan. Koefisen bernilai positif artinya terjadi hubungan positif, dimana Mutu Interaktif yang tinggi akan meningkatkan Kepuasan Pelanggan.

\section{Uji Hipotesis (Uji T)}

Pengujian ini dilakukan untuk menentukan signifikan atau tidak signifikan terikat. Hipotesis pengujian parsial adalah :

$\mathrm{H}_{0}: \mathrm{H}_{\mathrm{i}}=0$ (berarti tidak ada pengaruh parsial signifikan dari $\mathrm{X}$ terhadap $\mathrm{Y}$ )

$\mathrm{H}_{\mathrm{a}}: \mathrm{H}_{\mathrm{i}} \neq 0$ (berarti ada pengaruh parsial signifikan dari $\mathrm{X}$ terhadap $\mathrm{Y}$ )

Kriteria pengujian parsial adalah (Riduwan, 2009:160) : (1) Apabila $t_{\text {hitung }}<t_{\text {tabelpada }}$ taraf signifikansi $5 \%$ dan $10 \%(\alpha=0,05)$ dan $(\alpha=$ $0,10)$ maka tidak terdapat pengaruh signifikan dari variabel bebas terhadap variabel terikat. (2) Sebaliknya $t_{\text {hitung }}>t_{\text {tabel }}$ pada taraf signifikansi $5 \%$ dan $10 \%(\alpha=0,05)$ dan $(\alpha=$ $0,10)$ maka terdapat pengaruh signifikan dari variabel bebas terhadap variabel terikat.

Tabel 9. Hasil Uji Parsial ( Ujit ) Coefficients $^{\mathrm{a}}$

\begin{tabular}{llll}
\hline Variabel & $\mathbf{T}_{\text {tabel }}$ & $\mathbf{T}_{\text {hitung }}$ & Sig \\
\hline Mutu Fisik $\left(\mathrm{X}_{1}\right)$ & 2.366 & 3.791 & $.000^{* * *}$ \\
\hline $\begin{array}{l}\text { Pendukung } \\
\text { Mutu Fisik }\left(\mathrm{X}_{2}\right)\end{array}$ & 1.660 & .457 & .649 \\
\hline $\begin{array}{l}\text { Mutu } \\
\text { Perusahaan }\left(\mathrm{X}_{3}\right)\end{array}$ & 1.660 & .794 & .429 \\
\hline Mutu Teknikal & 1.984 & 2.105 & $.038^{* *}$ \\
\hline
\end{tabular}

\begin{tabular}{llll}
\hline$\left(\mathrm{X}_{4}\right)$ & & & \\
\hline $\begin{array}{l}\text { Mutu Interaktif } \\
\left(\mathrm{X}_{5}\right)\end{array}$ & 1.660 & .026 & .979 \\
\hline $\begin{array}{l}\text { Sumber: Data Olahan, } 2018 \\
\text { Sumber }\end{array}$
\end{tabular}

Berdasarkan pada tabel 9. diatas, maka hasil pengujian secara parsial dapat dijelaskan sebagai berikut

Hipotesis 1. artinya hasil pengujian menunjukkan bahwa nilai $\mathrm{T}_{\text {hitung }}$ untuk variabel Mutu Fisik sebesar $3.791>$ dari $\mathrm{T}_{\text {tabel }}$ sebesar 2.366 atau nilai signifikan $0.000<$ dari alpha 0.1 , maka $\mathrm{H}_{1}$ diterima, dengan berarti bahwa variabel Mutu Fisik berpengaruh signifikan terhadap kepuasan pelanggan gojek pada mahasiswa Pelita Indonesia di Pekanbaru.

Hipotesis 2 Artinya hasil pengujian menunjukkan bahwa nilai $\mathrm{T}_{\text {hitung }}$ untuk variabel Pendukung Mutu Fisik sebesar 0.457 $<$ dari $\mathrm{T}_{\text {tabel }}$ sebesar 1.660 atau nilai signifikan 0.649 > dari alpha 0.05 , maka $\mathrm{H}_{2}$ ditolak, dengan berarti bahwa variabel Pendukung Mutu Fisik berpengaruh dan tidak signifikan terhadap kepuasan pelanggan gojek pada mahasiswa Pelita Indonesia di Pekanbaru.

Hipotesis 3 Artinya hasil pengujian menunjukkan bahwa nilai $\mathrm{T}$ hitung untuk variabel Mutu Perusahaan sebesar $0.794<$ dari $\mathrm{T}_{\text {tabel }}$ sebesar 1.660 dan nilai signifikan 0.000 < dari alpha 0.1, maka $\mathrm{H}_{3}$ ditolak, dengan berarti variabel Mutu Perusahaan berpengaruh dan tidak signifikan terhadap kepuasan pelanggan gojek pada mahasiswa Pelita Indonesia di Pekanbaru.

Hipotesis 4 artinya hasil pengujian menunjukkan bahwa nilai $\mathrm{T}$ hitung untuk variabel Mutu Teknikal sebesar $2.105>$ dari $\mathrm{T}_{\text {tabel }}$ sebesar 1.984 dan nilai signifikan $0.038<$ dari alpha 0.05 , maka $\mathrm{H}_{4}$ diterima,dengan berarti variabel Mutu Teknikal berpengaruh signifikan terhadap kepuasan pelanggan gojek pada mahasiswa Pelita Indonesia di Pekanbaru.

Hipotesis 5 artinya hasil pengujian menunjukkan bahwa nilai $\mathrm{T}$ hitung untuk variabel Mutu Interaktif sebesar $0.026>$ dari $\mathrm{T}_{\text {tabel }}$ sebesar 1.984 nilai signifikan $0.000<$ dari alpha 0.1, maka $\mathrm{H}_{5}$ diterima,dengan berarti variabel Mutu Interaktif berpengaruh signifikan terhadap kepuasan pelanggan gojek pada mahasiswa Pelita Indonesia di Pekanbaru. 


\section{Pengaruh Mutu Fisik Terhadap Kepuasan Pelanggan}

Berdasarkan hasil uji $t$ diketahui bahwa variabel Mutu Fisik memiliki pengaruh yang signifikan terhadap Kepuasan Pelanggan. Maka dengan demikian secara parsial dapat dinyatakan variabel Mutu Fisik berpengaruh nyata terhadap Kepuasan Pelanggan gojek pada mahasiswa Pelita Indonesia di Pekanbaru, hasil penelitian ini menunjukkan bahwa Mutu fisik merupakan kualitas dari segi fisik (Kenderaan) yang mampu mempengaruhi kepuasan pelanggan. Dari hasil penelitian yang pernah dilakukan oleh (Prastowo2010) bahwa mutu fisik memiliki pengaruh yang signifikan terhadap kepuasan konsumen, penelitian ini sejalan dengan penelitian yang dilakukan saat ini bahwa variabel mutu fisik berpengaruh signifikan terhadap kepuasan pelanggan gojek pada mahasiswa Pelita Indonesia Pekanbaru.

\section{Pengaruh Pendukung Mutu Fisik}

Berdasarkan hasil uji $\mathrm{t}$ diketahui bahwa variabel Pendukung Mutu Fisik tidak memiliki pengaruh yang signifikan terhadap kepuasan pengguna Go-Jek. Dengan demikian secara parsial dapat dinyatakan variabel Pendukung Mutu Fisik tidak berpengaruh nyata terhadap kepuasan pengguna Go-Jek pada mahasiswa Pelita Indonesia Pekanbaru, mengingat Pendukung mutu fisik adalah mutu/kualitas yang mendukung kinerja atau manfaat dari fasilitas fisik yang dapat mempengaruhi kepuasan pelanggan akan tetapi apabila mutu fisik telah dijaga dengan baik maka pendukung mutu fisik tersebut pasti sudah kelihatan baik. Dari hasil penelitian yang pernah dilakukan oleh (Anang (2016) bahwa pendukung mutu fisik memiliki pengaruh yang signifikan terhadap kepuasan konsumen dan penelitian ini pun tidak sejalan dengan penelitian yang dilakukan saat ini bahwa variabel pendukung mutu fisik tidak berpengaruh signifikan terhadap kepuasan pelanggan Go-Jek pada mahasiswa Pelita Indonesia Pekanbaru.

\section{Pengaruh Mutu Perusahaan Terhadap Kepuasan Pelanggan}

Berdasarkan hasil uji $\mathrm{t}$ diketahui bahwa variabel Mutu Perusahaan tidak memiliki pengaruh yang signifikan terhadap kepuasan pengguna. Dengan demikian secara parsial dapat dinyatakan variabel Mutu
Perusahaan tidak berpengaruh nyata terhadap kepuasan pelanggan terhadap gojek pada mahasiswa Pelita Indonesia Pekanbaru, mengingat Pendukung Adalah mutu/kualitas dari perusahaan atau lembaga penyedia layanan, yang dapat mempengaruhi kepuasan pelanggan dan biasanya didasarkan pada kinerja operasional perusahaan. Oleh karena itu apabila kualitas jasanya baik maka orang tidak akan peduli tentang dari mana perusahaan itu berasal. Dari hasil penelitian yang pernah dilakukan oleh (Ika \& Pungki 2011) bahwa bahwa pendukung mutu perusahaan memiliki pengaruh yang signifikan terhadap kepuasan konsumen dan penelitian ini pun tidak sejalan dengan penelitian yang dilakukan saat ini bahwa variabel pendukung mutu perusahaan tidak berpengaruh signifikan terhadap terhadap kepuasan pelanggan terhadap gojek pada mahasiswa Pelita Indonesia Pekanbaru.

\section{Pengaruh Mutu Teknikal Terhadap Kepuasan Pelanggan}

Berdasarkan hasil uji $\mathrm{t}$ diketahui bahwa variabel Mutu teknikal memiliki pengaruh yang signifikan terhadap Kepuasan Pelanggan. Maka dengan demikian secara parsial dapat dinyatakan variabel Mutu teknikal berpengaruh nyata terhadap Kepuasan Pelanggan terhadap gojek pada mahasiswa Pelita Indonesia di Pekanbaru, hasil penelitian ini menunjukkan bahwa Mutu teknikal adalah Mutu teknikal adalah mutu/kualitas dari segi teknis dalam hal pelayanan yang dapat mempengaruhi kualitas pelanggan. Dari hasil penelitian yang pernah dilakukan oleh (Ika \& Pungki 2011) bahwa bahwa pendukung mutu teknikal memiliki pengaruh yang signifikan terhadap kepuasan konsumen dan penelitian ini pun sejalan dengan penelitian yang dilakukan saat ini bahwa variabel pendukung mutu teknikal berpengaruh signifikan terhadap terhadap kepuasan pelanggan terhadap gojek pada mahasiswa Pelita Indonesia Pekanbaru.

\section{Pengaruh Mutu Interaktif Terhadap Kepuasan Pelanggan}

Berdasarkan hasil uji $t$ diketahui bahwa variabel Mutu interaktif tidak memiliki pengaruh yang signifikan terhadap Kepuasan Pelanggan. Maka dengan demikian secara parsial dapat dinyatakan variabel Mutu interaktif tidak berpengaruh nyata terhadap Kepuasan Pelanggan terhadap gojek pada 
mahasiswa Pelita Indonesia di Pekanbaru, hasil penelitian ini menunjukkan bahwa Mutu interaktif adalah mutu/kualitas yng dinilai dengan performa dan kualitas interaktif atau kemampuan berkomunikasi pihak perusahaan dengan pelanggan dan hal ini dapat mempengaruhi kepuasan pelanggan tersebut maka semakin baik karyawan berkomunikasi maka pelanggan akan semakin puas. Dari hasil penelitian yang pernah dilakukan oleh (Ika \& Pungki 2011) bahwa pendukung mutu interaktif memiliki pengaruh yang signifikan terhadap kepuasan konsumen dan penelitian ini pun tidak sejalan dengan penelitian yang dilakukan saat ini bahwa variabel pendukung mutu interaktif tidak berpengaruh signifikan terhadap terhadap kepuasan pelanggan terhadap gojek pada mahasiswa Pelita Indonesia Pekanbaru.

\section{PENUTUP}

Dari hasil pengujian hipotesis yang telah dilakukan maka dapat disimpulkan sebagai berikut: (1) Mutu Fisik mempengaruhi kepuasan pelanggan secara signifikan Pada mahasiswa pengguna Go-Jek di Perguruan Tingi Pelita Indonesia Pekanbaru. (2) Pendukung Mutu Fisik tidak mempengaruhi kepuasan konsumen secara signifikan Pada Mahasiswa Pengguna Go-jek di Perguruan Tinggi Pelita Indonesia Pekanbaru. (3) Mutu Perusahaan tidak mempengaruhi kepuasan Pelanggan secara signifikan PadaMahasiswa Pengguna Go-jek di Perguruan Tinggi Pelita Indonesia Pekanbaru. (4) Mutu Teknikal mempengaruhi kepuasan Pelanggan Go-Jek secara signifikan pada mahasiswa Pengguna Go-Jek di Perguruan Tinggi Pelita Indonesia Pekanbaru. (5) Mutu Interaktif tidak mempengaruhi kepuasan Pelanggan secara signifikan Pada Mahasiswa Pengguna Go-jek di Perguruan Tinggi Pelita Indonesia Pekanbaru.

Berdasarkan hasil penelitian dan evaluasi, maka adapun saran yang dapat diberikan peneliti adalah sebagai berikut ;

1. Bagi perusahaan, untuk meningkatkan mutu fisik, perusahaan harus lebih membuat tampilan aplikasi lebih menarik lagi, itu mungkin bisa ditambah dengan adanya tema-tema agar konsumen tidak merasa bosan karena dalam aspek mutu fisik berpengaruh terhadap kepuasan konsumen. Dan pada segi mutu teknikal perusahaan sebaiknya memberikan penyuluhan kepada driver agar peka terhadap apa permintaan konsumen, hal ini dikarenakan mutu teknikal berpengaruh terhdap kepuasan konsumen, maka oleh sebab itu sebaiknya perusahaan harus mengerti apa yang di inginkan konsumen. Dan untuk pendukung mutu fisik walaupun tidak berpengaruh terhadap kepuasan konsumen pada penelitian ini, bukan berarti pendukung mutu fisik tidak penting karena dilihat dari analisis deskriptif dapat dilihat bahwa pernyataan tentang menjaga keselamatan konsumen mendapat nilai paling rendah, maka untuk itu perusahaan harus menjaga keselmatan para pengguna nya ataupun konsumennya hal ini sebaiknya dilakuan dengan mewajibkan pengendara ojek online wajib mematuhi ketertiban berlalu lintas. Begitpun dari segi mutu perusahaan, dan mutu interaktif walaupun tidak berpengaruh terhadap kepuasan konsumen bukan berarti tidak penting. Karena dengan mutu perusahaan dan mutu interaktif yang baik maka itu akan membuat konsumen merasa puas hal ini dapat dilihat dari analisis deskriptif konsumen kurang merasa puas terhadap ketepatan waktu hal ini dapat di perbaiki dengan memberikan driver yang terdekat dengan konsumen terdekat agar mudah mencapai jarak konsumen dan konsumen akan merasa puas terhadap ketepatan waktu. Dan untuk mutu interkatif sebaiknya konsumen selalu memberikan informasi dengan baik terhadap para konsumen nya karena dengan adanya informasi yang baik maka konsumen akan lebih mudah mengetahui tentang perusahaan maka itu akan menciptkan kepuasan konsumen.

2. Bagi Akademis, hasil dari penelitian ini dapat dijadikan sebagai penambah referensi oleh pihak lain yang melakukan penelitian untuk permasalahan yang sama dimasa yang akan datang, dan bagi peneliti selanjutnya diharapkan dapat menambah variabel lain diluar variabel yang sudah diteliti dalam penelitian ini agar memperoleh hasil yang bervariasi yang dapat berpengaruh terhadap kepuasan pelanggan. 
DAFTAR PUSTAKA

Aprinawati (2011). Pengaruh Kondisi Fisik Terhadap Kepuasan Konsumen pada Bus Damri Jurusan MedanLubuk Pakam. Jurnal Keuangan \& Bisnis, Vol, No.1, Maret 2011.

Assauri, Sofian. 2010. Manajemen Pemasaran: Dasar, Konsep \& Strategi. Jakarta: Raja Grafindo Persada.

Abdullah, Thamrin \& Francis Tantri. 2012 Manajemen Pemasaran. Jakarta Rajagrafindo Persada.

Darmansyah. (2012). Pengaruh Total Quality Service Terhadap Kepuasan Nasabah Pada Bank Syariah di Bengkulu. Jurnal Aplikasi Manajemen, Vol. 10. No.4, Desember 2012. Bhawika, G. W., Purwantoro, P., Daengs, G. A., Sudrajat, D., Rahman, A., Makmur, M., .. \& Wanto, A. (2019, August). Implementation of ANN for Predicting the Percentage of Illiteracy in Indonesia by Age Group. In Journal of Physics: Conference Series (Vol. 1255, No. 1, p. 012043). IOP Publishing.

Heizer, Jay \& Render Barry.2015.Manajemen Operasi: Manajemen Keberlangsungan dan Rantai Pasokan, edisi 11.Jakarta:SalembaEmpat.

Irawan, H. (2004) Indonesian Customer Satisfaction: Membedah Strategi Kepuasan Pelanggan Merek Pemenang ICSA. Jakarta : PT Alex Media Komputindo

Ika Nurul Qamari \& Pungki Afrizan Rahman. (2011). Analisis Pengaruh Service Quality Management Terhadap

Kepuasan Pelanggan. Jurnal Maksimum. Vol, No, Maret 2011.

Kotler P \& K L Keller. (2016) Manajemen Pemasaran, Edisi ke 15. Jakarta Macan Jaya Cemerlang

Kotler philip, 2002, Manajemen Pemasaran, edisi Melenium, terjemahan Hendra Teguh, dan Ronny A. Rusli , Penerbit : Prenhallindo, Jakarta

Kotler, Philip dan Kevin, Keller. 2008 Manajemen Pemasaran. Alih bahasa Benyamin Molan. Edisi Dua Belas. Jakarta; PT. INDEKS.

Kotler, philip \& Amstrong, Gary, (2014) Prinsip-Prinsip Manajemen. Edisi 1 Jakarta: Erlangga.
Lupiyoadi Rambat, dan Hamdani. 2006 Manajemen Pemasaran Jasa. edisi Kedua.Jakarta; Salemba Empat.

Mujiati Munawaroh. (2015). Manajemen Operasi Yogyakarta: UPFE UMY.

Maranto Riyohi Anang Pengaruh Total Service Quality Management Terhadap Kepuasan Pelanggan PO. Maju Lancar Di Yogyakarta Fakultas Ekonomi dan Bisnis Universitas Muhamadiyah Yogyakarta.

Malhotra, 2015, Riset Pemasaran . Edisi 4 PT. Indeks, Jakarta

Lupiyoadi Rambat, dan Hamdani. 2006 Manajemen Pemasaran Jasa. edisi Kedua.Jakarta; Salemba Empat.

Riduan. (2009). Dasar-Dasar Statiska. Bandung: Alfabeta.

Sugiyono, 2009, metode Penelitian Bisnis, Alfa Betha, Bandung.

Solihin Ismail. 2010. Pengantar Manajemen, Erlangga, Jakarta.

Suryo Adi, Prastowo. (2010). Pengaruh Total Service Quality Management Terhadap Kepuasan Pelanggan. Yogyakarta UPFE UMY.

Siregar, Sofyan. (2011). Statiska Deskriptif Untuk Penelitian. Jakarta : PT Raja Grafindo Persada

Tjiptono Fandy. (2005) Pemasaran Jasa, Edisi Pertama. Yogyakarta; Penerbit Bayumedia Publishing. 